Contents list available at IJRED website

Int. Journal of Renewable Energy Development (IJRED)

Journal homepage: http://ejournal.undip.ac.id/index.php/ijred

\title{
Performance, Emissions and Combustion Characteristics of a Single Cylinder Diesel Engine Fuelled with Blends of Jatropha Methyl Ester and Diesel
}

\author{
Debasish Padhee ${ }^{\mathrm{a},{ }^{*}, \text { and Hifjur Raheman }}{ }^{\mathrm{b}}$ \\ a Department of Farm Machinery \& Power, BRSM CAET, Mungeli, Chhattisgarh, INDIA \\ ${ }^{b}$ Department of Agricultural \& Food Engineering, IIT, Kharagpur, West Bengal, INDIA
}

\begin{abstract}
In order to meet the energy requirements, there has been growing interest in alternative fuels like biodiesels, ethyl alcohol, biogas, hydrogen and producer gas to provide a suitable diesel substitute for internal combustion engines. An experimental investigation was performed to study the performance, emissions and combustion characteristics of diesel engine fuelled with blends of Jatropha methyl ester and diesel. In the present work three different fuel blends of Jatropha methyl ester (B10, B20, B40 and B100) were used. The increments in load on the engine increase the brake thermal efficiency, exhaust gas temperature and lowered the brake specific fuel consumption. The biodiesel blends produce lower carbon monoxide \& unburned hydrocarbon emission and higher carbon dioxide \& oxides of nitrogen than neat diesel fuel. From the results it was observed that the ignition delays decreased with increase in concentration of biodiesel in biodiesel blends with diesel. The combustion characteristics of single-fuel for biodiesel and diesel have similar combustion pressure and HRR patterns at different engine loads but it was observed that the peak cylinder pressure and heat release rate were lower for biodiesel blends compared to those of diesel fuel combustion.
\end{abstract}

Keywords: Biodiesel, Engine Performance, Cylinder Pressure, Ignition Delay, Heat Release Rate

Article History: Received January 2, 2014; Received in revised form March 25, 2014; Accepted June 15, 2014; Available online

How to Cite This Article: Padhee, D. \& Raheman, H. (2014) Cylinder Diesel Engine Fuelled with Blends of Jatropha Methyl Ester and Diesel. Int. Journal of Renewable Energy Development, 3(2), 125-131. http://dx.doi.org/10.14710/ijred.3.2.125-131

\section{Introduction}

Rising oil prices and growing climate change concerns are contributing to the consideration of alternatives to replace and substantially reduce dependency on fossil fuels. Biofuels are seen as an attractive energy option because of their potential to substitute fossil fuels, increase energy security, apparent price competitiveness in comparison to oil, offer new market opportunities, regenerate degraded land and reduce GHG (greenhouse gas) emissions among others. On this contrast vegetable oils have come up as a promising source of biofuel. The vegetable oils due to their high density and viscosity cannot be used in non-modified diesel engines, so they are used in esterified (biodiesel) forms. Their use in form of methyl esters in non-modified engines has given encouraging results. Use of edible oil to produce biodiesel in India is also not feasible in view of big gap in demand and supply of such oils. Under Indian condition only such plants can be considered for biodiesel, which produce non-edible oil in appreciable quantity and can be grown on large scale on non-cropped marginal lands and waste lands. Out of many available non-edible vegetable crops, Jatropha curcas is the most widely used biodiesel crops. Several studies have been conducted using biodiesel produced from Jatropha curcas (Senthil et al. 2003; Reddy et al. 2006).

There has been a lot of research on biodiesel combustion, performance and emissions (Pramanik

\footnotetext{
* Corresponding author: +91- 9754431936

Email: itsmedebu@gmail.com
} 
2003; Forson et al. 2004; Ramdhas et al. 2004; Puhan et al. 2010; Xue et al. 2011). From the previous studies it was reported that the engine fuelled with biodiesel blends gives better performance with reduction in $\mathrm{HC}$ (hydrocarbon) and CO (carbon monoxide) emissions and increase in $\mathrm{NO}_{\mathrm{x}}$ (nitrogen oxides) emissions. An experimental investigation at Indian Institute of Technology, Kharagpur was made to evaluate the performance and emission characteristics of a diesel engine using different blends of methyl ester of Jatropha with diesel. This study was conducted to determine the suitability of Jatropha biodiesel (JB) as a substitute for diesel.

\section{Materials and Methods}

\subsection{Composition of Jatropha oil}

The basic composition of any vegetable oil is triglyceride, which is the ester of three fatty acids and one glycerol. The fatty acid composition of Jatropha oil is shown in Fig. 1 (Cheng et al. 2012).

\subsection{Biodiesel production}

A two step 'acid-base' process; acid-pretreatment followed by main base-transesterification reaction; using methanol as reagent and $\mathrm{H}_{2} \mathrm{SO}_{4}$ and $\mathrm{KOH}$ as catalysts for acid and base reactions, respectively, was followed to produce biodiesel from crude jatropha oil in a laboratory scale processor (Tiwari et al. 2007; Rajendra et al. 2009). Jatropha seed, oil extracted from seeds and biodiesel produced are shown in Fig. 2.

\subsection{Fuel properties}

The fuel properties were determined following the ASTM standards as given in Table 1 for crude jatropha oil (CJO), Jatropha methyl ester (B100) and its blends with varying proportion of high speed diesel from $10 \%$ to $40 \%$ by volume (B10, B20, and B40).

\subsection{Experimental set up}

The jatropha biodiesel (B100), high speed diesel and their blends (B10, B20, and B40) were used to test a single cylinder, four stroke, water cooled, constant speed, direct injection diesel engine with the specifications shown in Table 2 . The engine was coupled with an electric generator of 5 KVA capacities and loaded by load bank consisting of electric heaters and bulbs to apply different engine loads. A Chromel-Alumel thermocouple with a digital display meter was used to measure the exhaust gas temperature. The performance of the engine and emissions were studied at 25\%, 50\%, $75 \%$, and $100 \%$ of the load corresponding to the load at maximum power at an average speed of $1500 \mathrm{rpm}$. After the engine reached the stabilized working condition, fuel consumption, torque applied and exhaust temperature were measured from which brake specific fuel consumption, brake thermal efficiency were computed. The emissions from the engine are measured after the engine reached the steady working condition. An Indus make online exhaust gas analyzer is used to measure the carbon monoxide (CO), carbon dioxide $\left(\mathrm{CO}_{2}\right)$, hydrocarbon emission (HC) and nitrous oxides (NOx). Engine speed was measured by a digital tachometer with a resolution of $1 \mathrm{rpm}$. In-cylinder pressure was measured using a Kistler water-cooled piezoelectric pressure transducer which was mounted on the cylinder head and was sampled every one degree crank angle. Crankshaft position was obtained using a rotary encoder to determine cylinder gas pressure as a function of crank angle. The layout of the experimental setup is shown in Fig. 3. Each reading was obtained thrice to obtain a reasonable value.

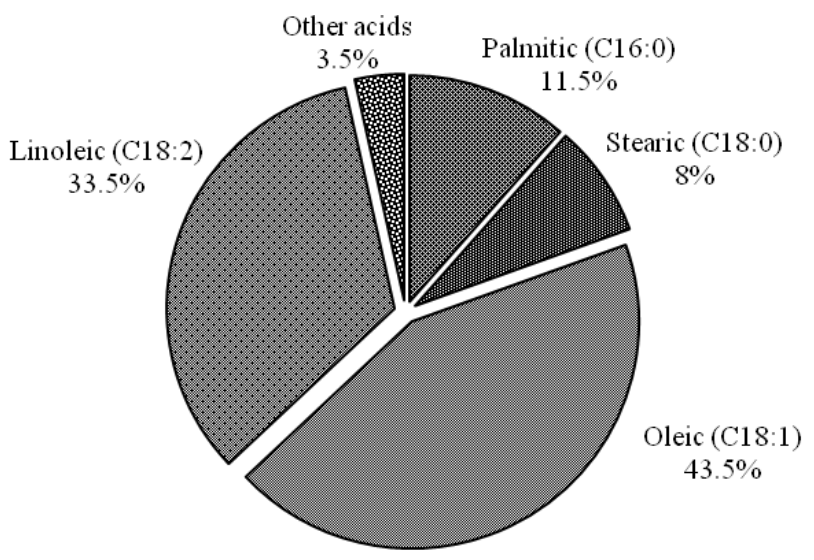

Fig. 1 Fatty acid composition of Jatropha oil

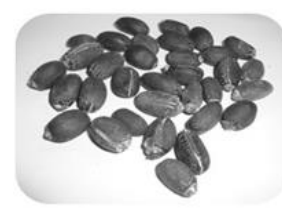

Jatropha seed

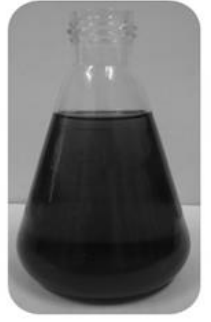

Jatropha oil

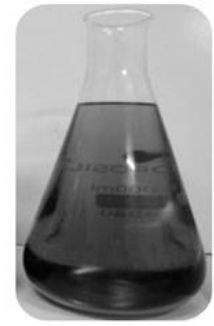

Jatropha biodiesel
Fig. 2 Jatropha seed, oil and biodiesel

Table 1

ASTM Standards used for determination of fuel properties

\begin{tabular}{|c|c|c|c|}
\hline Property & Unit & Standard & Instrument \\
\hline Density & $\mathrm{kg} / \mathrm{m}^{3}$ & D 4052-96 & Relative density bottle \\
\hline Viscosity & $\mathrm{mm}^{2} / \mathrm{s}$ & D 445-03 & Redwood viscometer \\
\hline $\begin{array}{l}\text { Calorific } \\
\text { value }\end{array}$ & $\mathrm{MJ} / \mathrm{kg}$ & D 240-02 & Bomb calorimeter \\
\hline Acid value & $\begin{array}{l}\mathrm{mg} \\
\mathrm{KOH} / \mathrm{g}\end{array}$ & D 5555-95 & Standard titrimetry \\
\hline Flash point & ${ }^{\circ} \mathrm{C}$ & D 93-02a & $\begin{array}{l}\text { Pensky martens closed } \\
\text { cup }\end{array}$ \\
\hline Ash content & $\%$ & D 97-02 & Pour point apparatus \\
\hline $\begin{array}{l}\text { Water } \\
\text { content }\end{array}$ & $\mathrm{v} / \mathrm{v}(\%)$ & D 95-990 & $\begin{array}{l}\text { Karl Fischer Titration } \\
\text { Apparatus }\end{array}$ \\
\hline
\end{tabular}




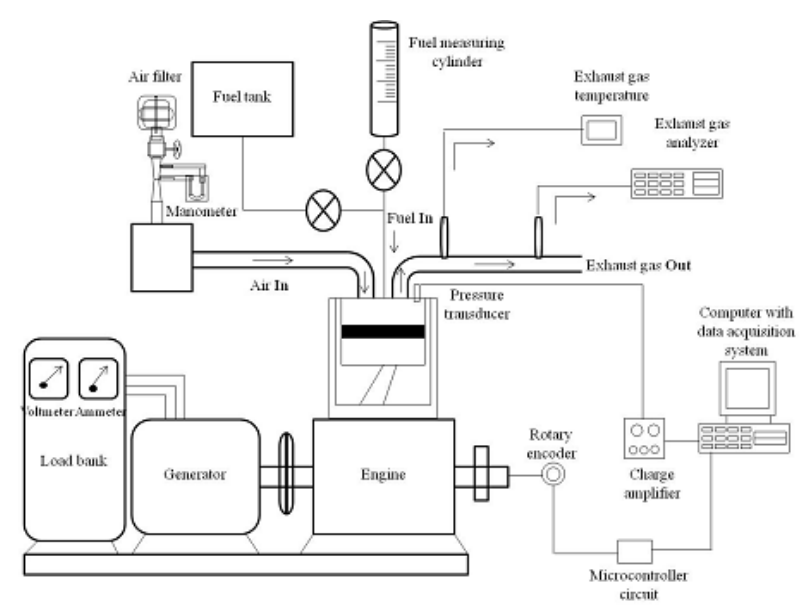

Fig. 3 Experimental setup

Table 2

Test engine specifications

\begin{tabular}{ll}
\hline Items & Specifications \\
\hline Make and model & Field Marshal - GF3BMG \\
Rated power output & $7.5 \mathrm{hp}$ \\
Rated speed (constant) & $1500 \mathrm{rpm}$ \\
Bore $\times$ Stroke & $87.5 \mathrm{~mm} \times 110 \mathrm{~mm}$ \\
Compression ratio & $16: 1$ \\
Fuel injection system & In-line, direct injection \\
Method of cooling & Water cooling \\
\hline
\end{tabular}

\section{Results and Discussion}

\subsection{Fuel characteristics}

After esterification, the colour of jatropha oil changed from deep brown to reddish yellow and on an average $900 \mathrm{ml}$ of jatropha methyl ester (biodiesel) was obtained from $1 \mathrm{l}$ of jatropha oil. The measured properties are presented in Table 3.

Fig. 4 show that the densities of fuel blends were observed to increase linearly with increase in concentration of biodiesel in the blends. The calorific values of the blends decreased proportionately with increase in biodiesel percentage in the blends. The kinematic viscosity of jatropha oil was found to be 8 times more than that of diesel determined at $40^{\circ} \mathrm{C}$. After esterification, the kinematic viscosity reduced to 2.15 times than that of pure jatropha oil. It further reduced with increase in diesel amount in the blend. A similar reduction in specific gravity was also observed. However, the calorific value of biodiesel was found to be $36.61 \mathrm{MJ} / \mathrm{kg}$, which is less than the calorific value of diesel $(42.4 \mathrm{MJ} / \mathrm{kg})$ and greater than that of the jatropha oil (36.53 MJ/kg). As the percentage of biodiesel in the blends increased, the calorific value decreased. The flash points of jatropha oil and biodiesel were found to be greater than $100^{\circ} \mathrm{C}$, which is safe for storage and handling.

\subsection{Performance of diesel engine}

\subsubsection{Brake specific fuel consumption (BSFC)}

BSFC of the engine decreased with increase in the engine load for all the fuels tested as evident from Fig. 5 This was due to the higher percentage increase in brake power with increase in engine load as compared to the increase in fuel consumption due to relatively less heat losses at higher engine loads.

It was also found that the BSFC increased with increasing concentration of biodiesel in the fuel blends with diesel. The higher fuel consumption for JB and its blends could be primarily related to the combined effect of higher density and lower energy content of higher biodiesel blend fuels as compared to diesel. BSFC was calculated on mass basis. Higher density of biodiesel blends caused higher mass injection for the same displacement of the plunger in the fuel injection pump. Thus, with the use of biodiesel, higher mass of fuel was consumed to achieve similar power causing an increase in the BSFC. Another possible reason might be the lesser ignition delay period of jatropha biodiesel which resulted in early start of combustion and led to a significant pressure rise before TDC. This might be contributing to increased compression work and heat loss resulting in increased fuel consumption.

\subsubsection{Brake thermal efficiency (BTE)}

BTE of the engine increased with increase in the engine load for all the fuels tested as evident from Fig. 6. The improved BTE at higher load was due to the reduction in friction loss and increase in brake power with increase in percent load.

Though the presence of inbuilt oxygen improved the combustion of biodiesel, the BTE in general decreased with increasing proportion of biodiesel in the fuel blends with diesel. This considerable reduction in brake thermal efficiency in biodiesel blends might be due to the lower calorific value of the blends compared to pure diesel.

\subsubsection{Exhaust gas temperature (EGT)}

The variations of EGT with load for diesel, JB their blends are shown in Fig. 7. It can be seen from this figure that EGT increased with increase in engine load but decreased with increase in biodiesel concentration in the blends with diesel. The increase in EGT with engine load was mainly due to increase in the amount of energy released at higher loads because of the burning of increased amount of fuel which was injected to meet the extra power requirement to take up the additional loading; hence more heat rejection to the exhaust gases. The decrease in EGT for JB may be due to shorter ignition delay of biodiesel, which resulted in early start of combustion, which in-turn decreased the heat release rate in the later phase of combustion and hence lowered the EGT for Jatropha biodiesel.

\subsubsection{Emission characteristics}

Carbon monoxide (CO) - It can be seen from the Fig. 8 that CO initially decreased with increase in engine load 
and later it increased with further increase in engine load for all the fuels tested. Initially, at lower engine loadings, cylinder temperature might be too low, which increased with engine loading due to higher quantity of heat release during the burning of higher quantity of fuel injected inside the cylinder. The increased cylinder temperature at higher engine loads prompted relatively better burning of the fuel resulting in decreased CO. However, with further increase in engine load beyond $70 \%$, CO emission increased due to incomplete combustion of the excess fuel injected into the combustion chamber owing to lower air-fuel ratio which might have prevented oxidation of $\mathrm{CO}$ into $\mathrm{CO}_{2}$.

It was observed that the emission of $\mathrm{CO}$ decreased with increasing proportion of jatropha biodiesel in the fuel blends. This was due to the presence of more inbuilt oxygen in the blends with higher biodiesel concentration, which led to relatively better combustion of the fuel resulting in lower $\mathrm{CO}$ emission.
Carbon dioxide $\left(\mathrm{CO}_{2}\right)$ - Emission of $\mathrm{CO}_{2}$ is greatly affected by engine loadings as evident from Fig. 9. It can be seen from the figure that the $\mathrm{CO}_{2}$ emission in general increased with increase in engine load. As the amount of fuel injected into the combustion chamber increased with engine load, quantity of fuel going through complete combustion also increased which resulted in increase in cylinder temperature. At elevated temperature, performance of the engine improved with relatively better burning of the fuel resulting in higher $\mathrm{CO}_{2}$ emission.

The $\mathrm{CO}_{2}$ emission in general was found to be increased significantly with increase in concentration of biodiesel in the fuel blends at any engine load tested. This could be attributed to the increase in the mass of fuel injected into the combustion chamber for biodiesel blends and better combustion of the injected fuel owing to the inherent oxygen present in the jatropha biodiesel

Table 3

Fuel properties of jatropha oil, jatropha methyl ester and its blends

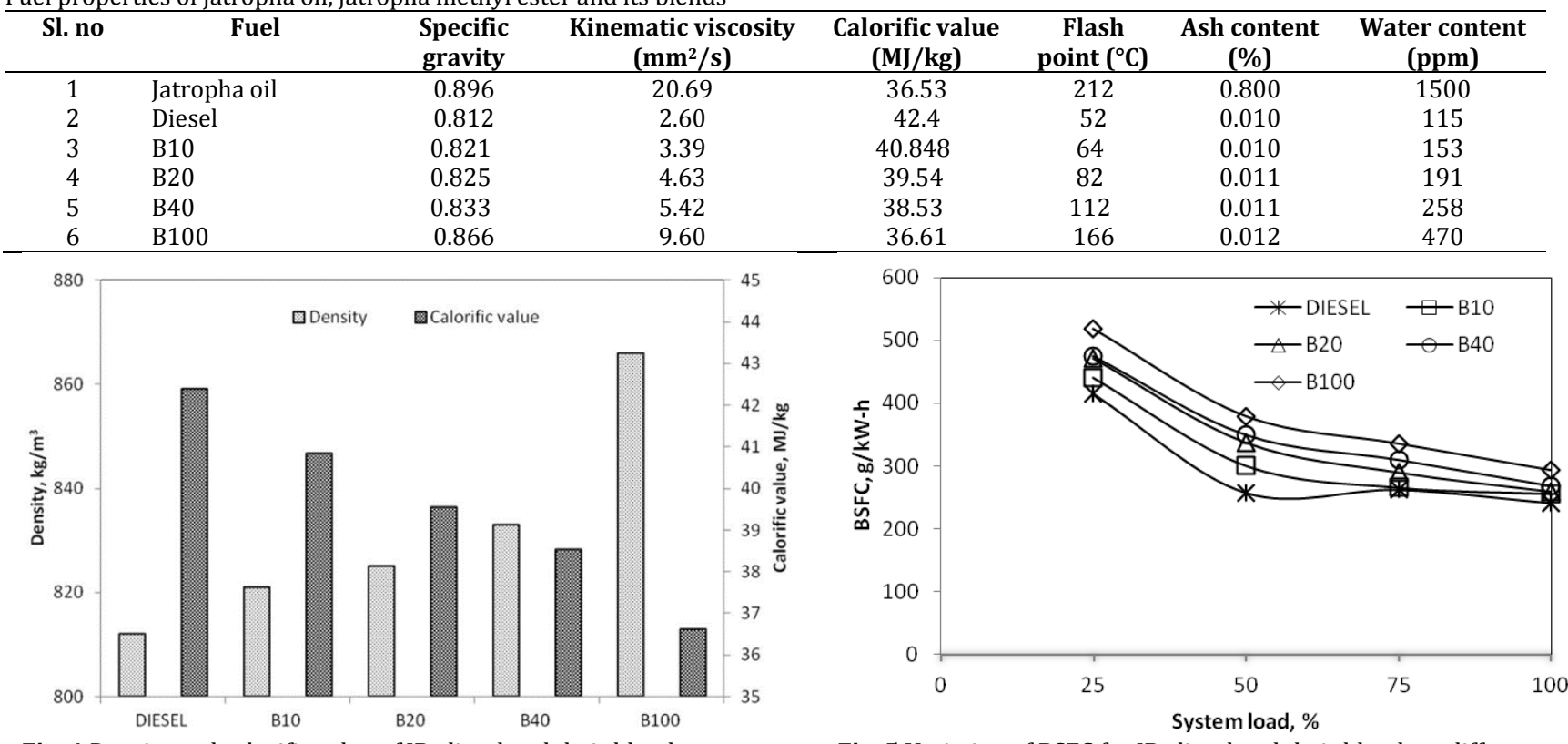

Fig. 4 Density and calorific value of JB, diesel and their blends

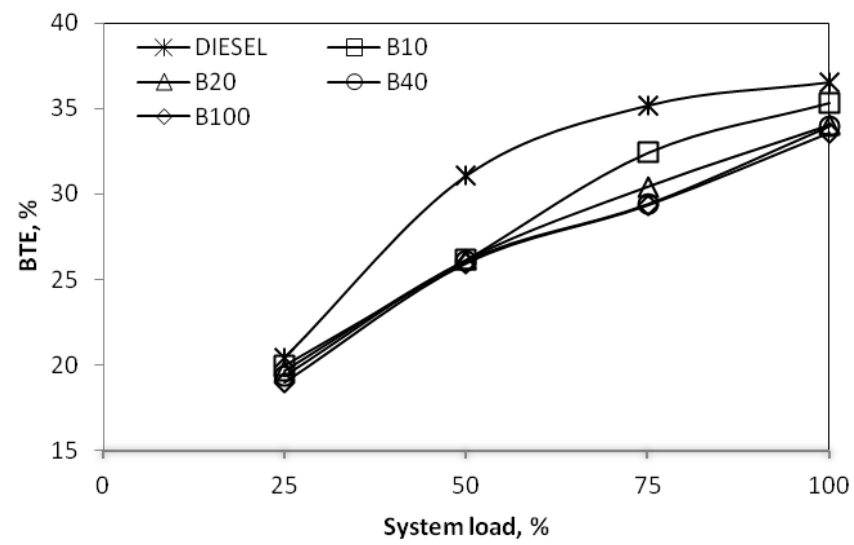

Fig. 6 Variation of BTE for JB, diesel and their blends at different system loads
Fig. 5 Variation of BSFC for JB, diesel and their blends at different system loads

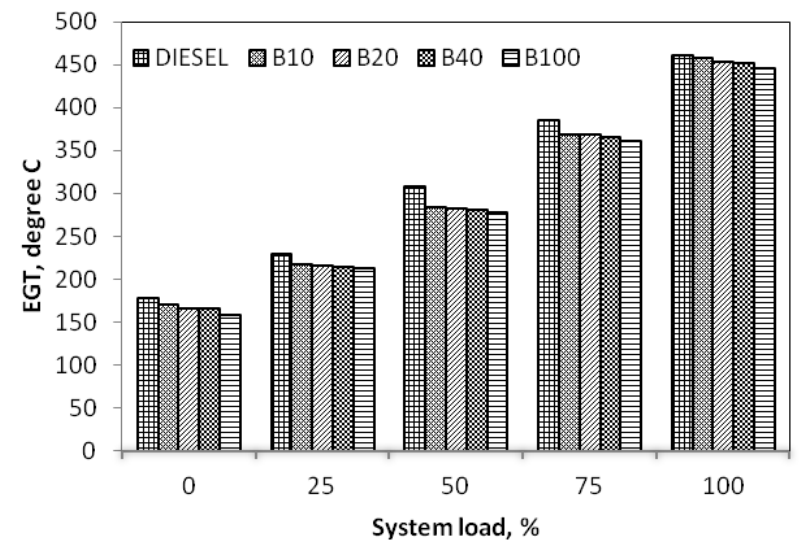

Fig. 7 Variation of EGT for JB, diesel and their blends at different system loads 
Oxides of nitrogen (NOx) - It can be seen from the Fig. 10 that the NOx concentration in emission increased with increase in engine load. As the engine load increased, average gas temperature in the combustion chamber also increased as a result of increased heat energy liberation from the fuel. This led to higher NOx emissions at higher loads.

The major factors of the NOx formation are high combustion temperature, rich local oxygen concentration, and long residence in the high temperature atmosphere. It can be seen that within the entire range of loading, the $\mathrm{NOx}$ emissions from the Jatropha biodiesel and its blends are higher than that of diesel fuel. The shorter ignition delay and the increased amount of biodiesel undergoing premixed combustion results in higher combustion temperature. The oxygen content in the biodiesel is the main reason for production of higher $\mathrm{NO}_{\mathrm{x}}$ for JB blends as compared to diesel because the oxygen in the biodiesel can react easily with nitrogen during the of combustion process, thus causing higher emissions of $\mathrm{NO}_{\mathrm{x}}$.

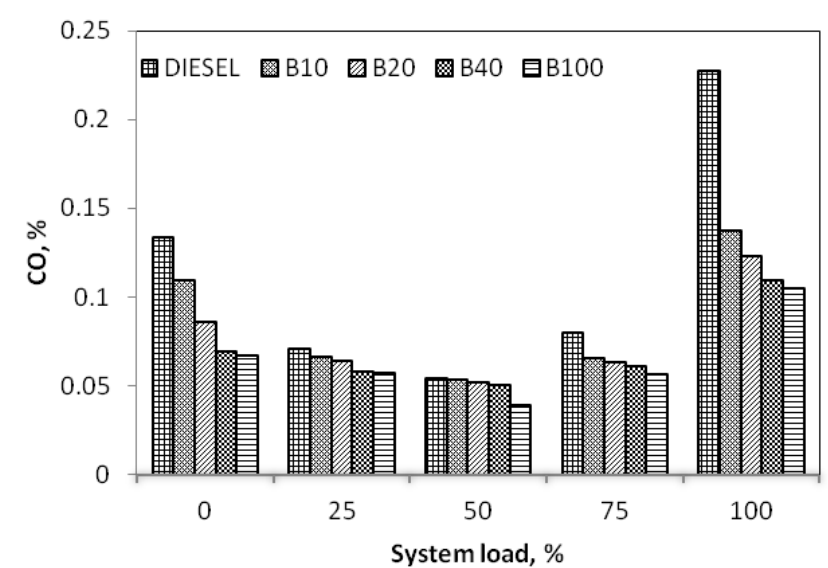

Fig. 8 Variation of CO for JB, diesel and their blends at different system loads

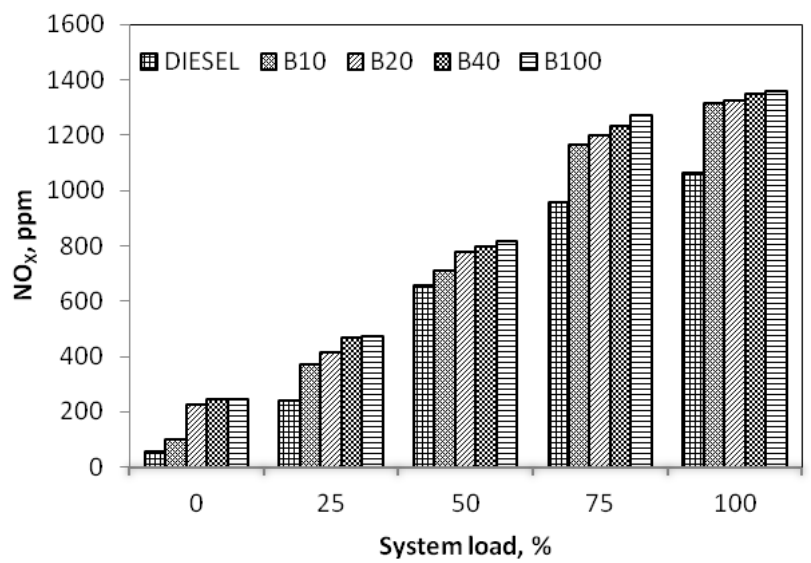

Fig. 10 Variation of NOx for JB, diesel and their blends at different system loads
Hydrocarbons (HC) - It can be observed from Fig. 11 that $\mathrm{HC}$ emissions in 0067eneral increased with increase in engine load. At higher load, the excess fuel required to meet the power requirement resulted in decreased airfuel ratio, consequently increasing the $\mathrm{HC}$ emissions sharply.

HC emissions were found to be lower for JB and its blends as compared to diesel over the entire range of engine loads. The reduction in $\mathrm{HC}$ emissions for biodiesel blends might be due to the presence of oxygen content in the biodiesel molecule, which led to a more complete and cleaner combustion.

\subsection{Combustion characteristics of jatropha biodiesel and diesel}

\subsubsection{Ignition delay}

Fig. 12 shows the reduction in the ignition delay with increasing load. This may be attributed to the higher combustion temperature and exhaust gas dilution at higher load. It was also observed that the ignition delay for biodiesels is generally shorter than diesel fuel.

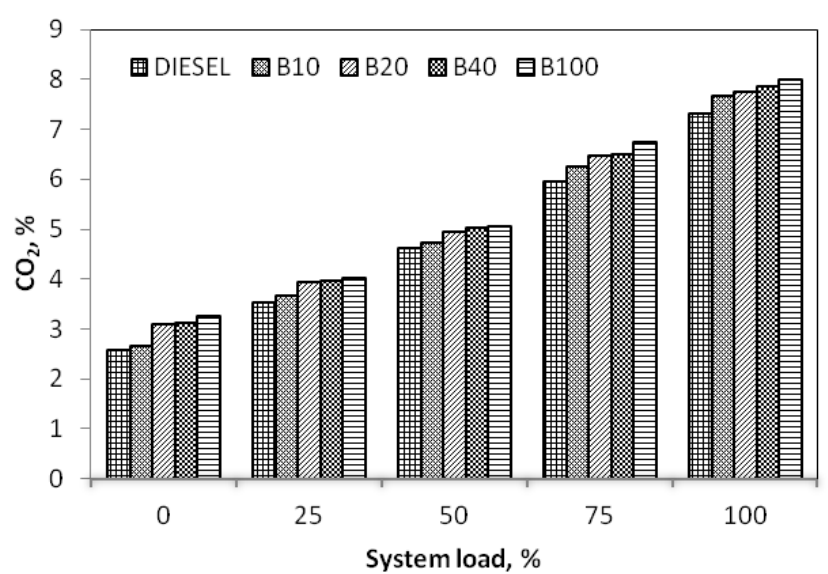

Fig. 9 Variation of $\mathrm{CO}_{2}$ for JB, diesel and their blends at different system loads

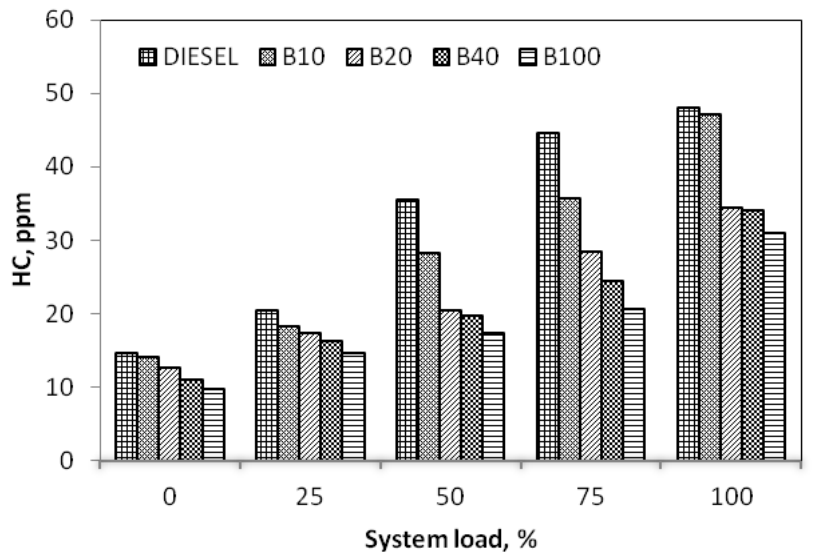

Fig. 11 Variation of HC for JB, diesel and their blends at different system load 
This shortening in ignition delay for biodiesel has been previously reported (Wang et al. 2000; Kalligeros et al. 2003). The main reason is because the cetane number for biodiesel is higher than diesel reducing the size of premixed combustion and thus reducing the ignition delay (Knothe 2005).

\subsubsection{Cylinder pressure}

The variation of peak cylinder gas pressure with crank angle and with system load for diesel, JB and their blends are compared in Fig. 13 and 14, respectively. It can be seen in these figures that the peak CGP increased with engine load for all the fuel tested. Since the quantity of fuel burned increased with engine load, it caused an increase in the heat energy released which resulted in an increase in peak CGP with load. It can also be observed from the figures that there is decrease in peak pressure for biodiesel blends compared to diesel fuel which might be due to the shortening in ignition delay, because under

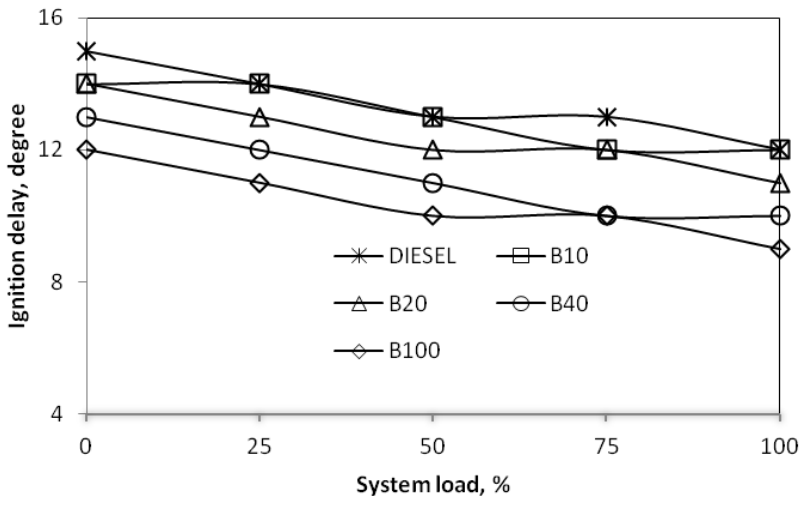

Fig. 12 Variation of Ignition delay for JB, diesel and their blends at different system loads

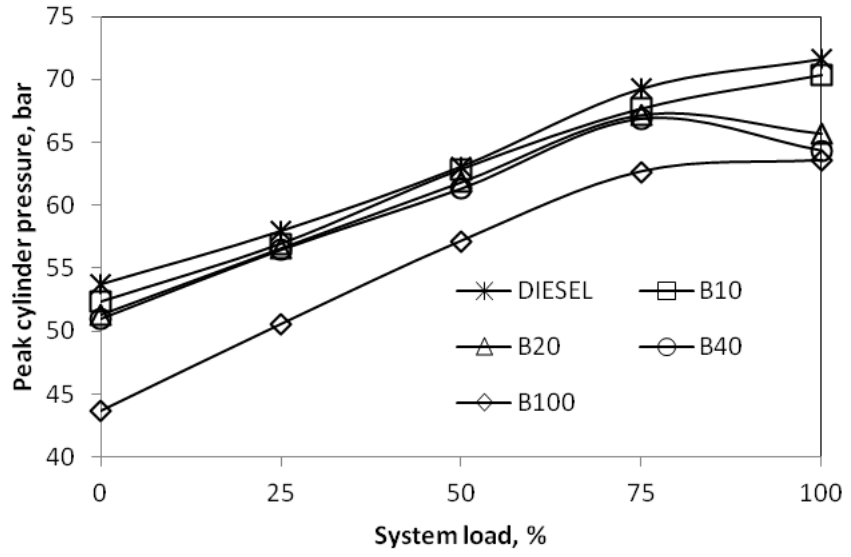

Fig. 14 Variation of Peak cylinder pressure for JB, diesel and their blends at different system loads the same experimental conditions if the delay period is shorter, biodiesel starts the combustion process earlier than diesel and therefore the temperatures and pressures inside the cylinder will be lower during the combustion.

\subsubsection{Heat release rate (HRR)}

It can be observed from the Figs. 15 and 16 that peak heat release rate is higher for diesel as compared to the biodiesel and their blends. This can be correlated with the combined effect of heating value and viscosity. The net heating value of as biodiesels and their blends were found to be lower than that of diesel (Table 3). Fuel with higher heating value can produce more amount of heat energy in a given time period and for a given fuel volume. In addition, if the viscosity is lesser, the evaporation rate will be faster and a larger amount of mixture can be expected for combustion.

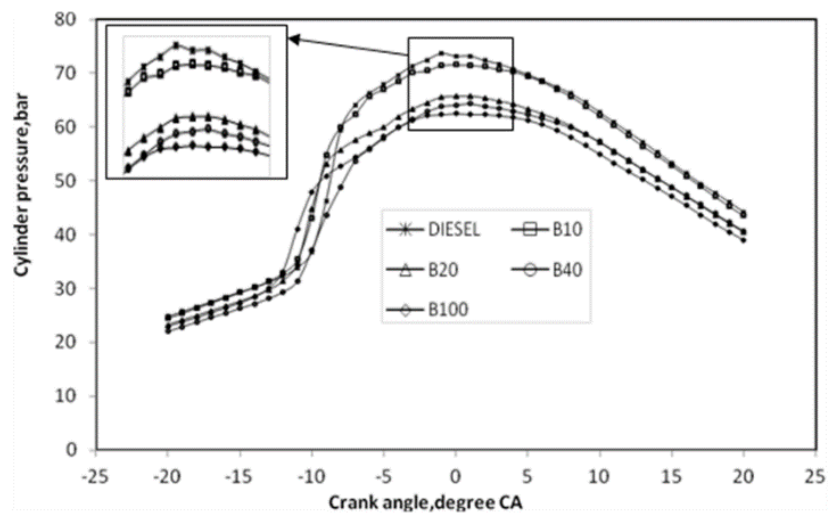

Fig. 13 Variations of cylinder gas pressure with respect to crank angle and fuel type at full load

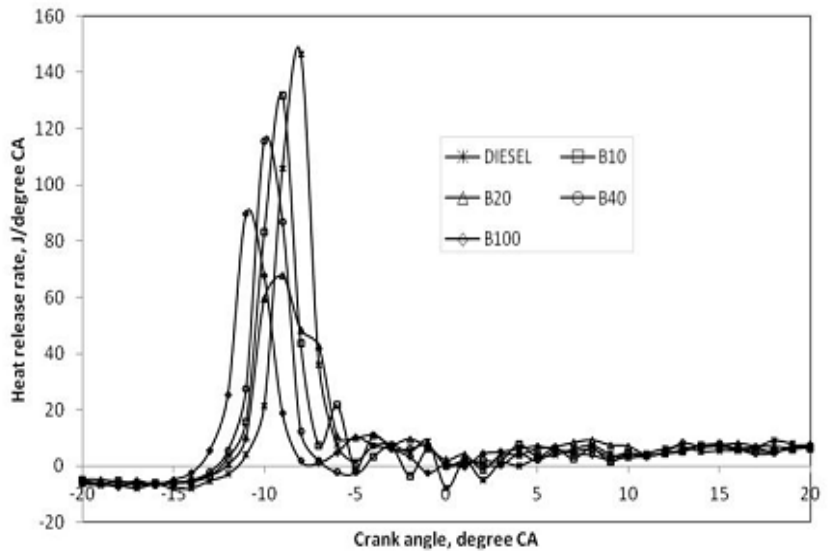

Fig. 15 Variation of heat release rate with change in crank angle at full load 


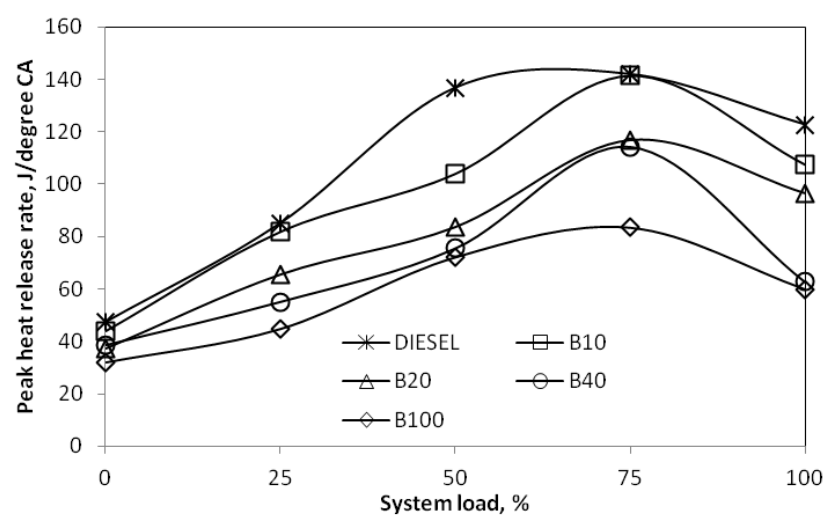

Fig. 16 Variation of Peak heat release rate for JB, diesel and their blends at different system loads

\section{Conclusions}

Performance, emissions and combustion characteristics of diesel engine has been studied experimentally using blends of Jatropha methyl esteer and diesel as fuel. The results showed that the biodiesel blends produce lower carbon monoxide and unburned hydrocarbon emission but higher oxides of nitrogen and exhaust gas temperature than neat diesel fuel. However, the level of emissions increased with increase in engine load for all fuels tested.

Biodiesel blends produce lower brake thermal efficiency and higher specific fuel consumption than diesel because of the low calorific value.

The combustion characteristics like peak cylinder pressure and heat release rate were found to be lower for biodiesel as compared to diesel at full load condition. It might be due to the combined effect of lower ignition delay and lower calorific value of biodiesel blends as compared to diesel.

From these findings, it can be concluded that B100 could be safely blended with diesel up to $20 \%$ without significantly affecting the engine performance (BSFC, BTE, EGT) and emissions (HC, $\mathrm{CO}$ and $\mathrm{NO}$ ) and thus could be a suitable alternative fuel for diesel.

\section{Acknowledgements}

The present study was conducted under the framework of the Department of Science and
Technology's project entitled "Power generation with reduced emissions using de-oiled cake and biodiesel from non-edible oil seeds". The authors wish to thank Department of Science and Technology, New Delhi, India for providing financial support.

\section{References}

Cheng, Y.Y., Fang, Z., Li, B. \& Long, Y. (2012) Review and prospects of Jatropha biodiesel industry in China. Renewable and Sustainable Energy Reviews, 16, 2178- 2190.

Forson, F.K., Oduro, E.K. \& Donkoh, E.H. (2004) Performance of jatropha oil blends in a diesel engine. Renewable Energy, 29, 1135-1145.

Kalligeros, S., Zannikos, F., Stouranas, S., Lois, E., Anastotoulus, G., Teas, S. Sakellaropoulou, F. (2003) An investigation of using biodiesel/marine diesel blends on the performance of a stationary diesel engine. Biomass \& Bioenergy, 24, 141-49.

Knothe, G. (2005) Dependence of biodiesel fuel properties on the structure of fatty acid alkyl esters. Fuel Processing Technology, $86,1059-70$.

Pramanik, K. (2003) Properties and use of jatropha curcas oil and diesel fuel blends in compression ignition engine. Renewable Energy, $28,239-248$

Puhan, S., Saravanan, N., Nagarajan, G. \& Vedaraman, N. (2010) Effect of biodiesel unsaturated fatty acid on combustion characteristics of a DI compression ignition engine. Biomass \& Bioenergy, 34, 1079-1088.

Rajendra, M., Jena, P.C. \& Raheman, H. (2009) Prediction of optimized pretreatment process parameters for biodiesel production using ANN and GA. Fuel, 88, 868-875.

Ramdhas, A.S., Jeyaraj, S. \& Muraleedharan, C. (2004) Use of vegetable oils as IC engines fuels - a review. Renewable Energy, 29, 727 742.

Reddy, J.N. \& Ramesh, A. (2006) Parametric studies for improving the performance of jatropha oil - fuelled compression ignition engine. Renewable Energy, 31, 1994 - 2016.

Senthil K.M., Ramesh, A. \& Nagalingam, B. (2003) An experimental comparison of methods to use methanol and jatropha oil in a compression ignition engine. Biomass \& Bioenergy, 25, 309318.

Tiwari, A.K., Kumar, A. \& Raheman, H. (2007) Biodiesel production from jatropha oil (Jatropha curcas) with high free fatty acids: An optimized process. Biomass and Bioenergy, 31 (8), 569-575.

Wang, W.G., Lyons, D.W., Clarck, N.N., Gautam, M. \& Norton, P.M. (2000) Emissions from nine heavy trucks fueled by diesel and biodiesel blend without engine modification. Environmental Science \& Technology, 34 (6), 933-39.

Xue, J., Grift, T.E. \& Hansen, A.C. (2011) Effect of biodiesel on engine performances and emissions. Renewable and Sustainable Energy Reviews, 15, 1098-1116. 